\title{
A SURPRISING EVOLUTION OF MYOCARDIAL INFARCTION IN YOUNG ADULTS
}

\author{
Cristina Adam², Magda Mitu, Dana Mîndru², Ana - Karina Gîlcă ${ }^{1}$, Mihai Roca ${ }^{1,3}$, Florin Mitu ${ }^{1,3}$ \\ ${ }^{1}$ Recovery Clinic Hospital, Cardiovascular Rehabilitation Iași \\ ${ }^{2}$ Cardiovascular Institute "Prof. Dr. George. I.M. Georgescu" Iași \\ ${ }^{3}$ "Grigore T. Popa" University of Medicine and Pharmacy, Iaşi \\ Corresponding author: \\ Cristina Adam \\ Recovery Clinic Hospital, Cardiovascular Rehabilitation Iași \\ e-mail: adam.cristina93@gmail.com
}

\section{Rezumat}

Introducere. Boala cardiacă ischemică este principala cauză de deces, având o prevalenţă în creştere. Infarctul miocardic acut este o consecinţă a ischemiei miocardice acute prelungite, ce apare secundar unui dezechilibru între consumul şi aportul de oxigen la acest nivel.

Prezentarea cazului. Prezentăm cazul unui pacient în vârstă de 53 ani, care se adresează clinicii noastre pentru reevaluare cardiovasculară, fiind simptomatic prin dispnee la eforturi medii, vertij intermitent și dureri musculare predominant la nivelul membrelor inferioare. La vârsta de 36 de ani pacientul suferă un infarct miocardic antero-lateral, trombolizat, complicat cu anevrism apical de ventricul stâng, în evoluție, cu apariția insuficienței cardiace cronice cu fracție de ejecție sever diminuată, motiv pentru care se introduce în schema terapeutică Sacubitril/Valsartan. Testarea cardiopulmonară de efort oferă cele mai bune informații referitoare la capacitățile funcționale, la pacientul nostru fiind realizată la 6 luni, respectiv un an de la introducerea inhibitorilor ARNI. Astfel, s-a observat o îmbunătățire a tuturor parametrilor urmăriți pe parcursul testǎrii cardiopulmonare, o atenție deosebită fiind atribuită creșterii răspunsului frecvenței cardiace la efort de la 113 bpm la 120 bpm (67\%, 82\% din valoarea prezisă).

Concluzii. Particularitatea acestui caz constă în apariția infarctului miocardic la o vârstă tânără (36 de ani) la un pacient fără antecedente heredocolaterale sau factori de risc asociați la momentul respectiv și care, după evenimentul acut, dezvoltă o insuficiență cardiacă cronică severă cu limitǎri importante ale calității vieții și prognosticului pe termen lung. Introducerea ARNI (Sacubitril/Valsartan) în schema terapeutică a determinat atât o ameliorare clinică, cât și paraclinică, la nivelul parametrilor ecocardiografici, fracția de ejecție crescând de la 25\% la începutul tratamentului la 40\% la ultima evaluare.

Cuvinte cheie: infarct miocardic, testare cardiopulmonară, ARNI, cardiopatie ischemică, recuperare. 


\title{
INTERNAL
}

Clinical Cases.

\begin{abstract}
Introduction. Ischemic heart disease is the leading cause of death with increasing prevalence. Acute myocardial infarction is a consequence of prolonged acute myocardial ischemia, which appears secondary to an imbalance between oxygen consumption and intake at this level.
\end{abstract}

Case report. We present the case of a male patient, aged 53 years old, admitted in the Cardiovascular Recovery Clinic for moderate dyspnea, intermittent dizziness and muscle pain predominantly in the lower limbs. Regarding his medical history, he suffered an antero-lateral myocardial infarction due to excessive physical effort, which was trombolysed. Following the remission of the acute episode, the evolution over the next 6-12 months was towards heart failure clinically manifested by dyspnea. Considering the presence of heart failure associated with severely diminished ejection fraction, the medication is adjusted and Sacubitril/Valsartan is introduced at a dose of 49/51 mg twice a day, under which our patient presents with both clinical and echocardiography improvement. Cardio-pulmonary stress testing is the most accurate as it provides the best information regarding functional capabilities, beyond the ejection fraction of the left ventricle. Following the treatment with RNAi (angiotensin receptorneprilysin inhibitor), the parameters evaluated during the stress test were improved, which is clinically transposed by improving the quality of life and implicitly the long-term prognosis.

Conclusion. The particularity of this case consists in the occurrence of myocardial infarction at a young age (36 years) in a patient without a heredocolateral history or associated risk factors at that time. The association of ARNI (Sacubitril / Valsartan) in the therapeutic scheme has determined a clinical improvement, as well as paraclinical especially regarding the echocardiographic parameters (the ejection fraction increased from $25 \%$ to $40 \%$ at the end of the evaluation).

Keywords: myocardial infarction, RNAi, ischemic heart disease, ergospirometry, recovery 


\section{Introduction}

Ischemic heart disease is the leading cause of death with increasing prevalence. Acute myocardial infarction is a consequence of prolonged acute myocardial ischemia, which appears secondary to an imbalance between oxygen consumption and intake at this level. Regarding the etiology of acute coronary syndromes, complicated atheroma plaque is considered the main pathogenic substrate. Cardiomyocyte necrosis is the result of occlusion of a large coronary artery secondary to intracoronary thrombosis which in turn complicates the evolution of a pre-existing atherosclerotic lesion.

\section{Case report}

We present the case of a male patient, aged 53 years old, admitted in the Cardiovascular Recovery Clinic for moderate dyspnea, intermittent dizziness and muscle pain predominantly in the lower limbs.

Regarding his medical history, he suffered an antero-lateral myocardial infarction due to excessive physical effort, which was trombolysed. Following the remission of the acute episode, the evolution over the next 612 months was towards heart failure clinically manifested by dyspnea. Initially, betablocker, angiotensin converting enzyme inhibitor, aldosterone antagonist, statin and aspirin were used at the doses recommended by the guidelines of the European Society of Cardiology. His medical history also included type 2 diabetes (diagnosed at the age of 38 years old) initially controlled with the help of dietary restrictions and oral antidiabetics, then also associated with insulin, high grade hypertension and dyslipidemia (diagnosed at the age of 48 years old). At first, treatment with atorvastatin is well tolerated, but later suggestive symptoms of statin intolerance such as muscular pain predominant in the limbs lower appear. Considering the presence of heart failure associated with severely diminished ejection fraction, the medication is adjusted and Sacubitril / Valsartan is introduced at a dose of $49 / 51 \mathrm{mg}$ twice a day, under which our patient presents with both clinical and echocardiography improvement. The patient has both deceased parents: the mother at the age of 47 years secondary to an complicated type 2 diabetes (left lower limb amputation and sepsis), and the father at the age of 84, without associated chronic pathology. As a personal pathological background, in addition to the above, the patient has an apical aneurysm of the left ventricle and diabetic sensory-motor polyneuropathy secondary to unbalanced diabetes, in the stage of both micro and macroangiopathic complications.

\section{Clinical examination:}

- nutrition status - overweight patient (waist $171 \mathrm{~cm}$, weight $89 \mathrm{~kg}$, abdominal perimeter $113 \mathrm{~cm}$, body mass index $28 \mathrm{~kg} / \mathrm{m} 2$ );

- cardiovascular status - blood pressure $135 / 80 \mathrm{mmHg}$, heart rate 73 beats/minute, rhythmic cardiac noises, apparently without over-added breaths, peripheral arteries weakly pulsed bilaterally;

- digestive tract: enlarged abdomen by volume on account of adipose panicle.

Given the symptomatology described by the patient and the clinical signs identified during the general clinical examination, the clinical conclusion is that we are in front of a patient with old and thrombolysed antero-lateral myocardial infarction, who presents as particularities: intolerance to statin and the treatment of heart failure. 


\section{INTERNAL}

\section{Clinical Cases}

\section{Investigations}

Usual laboratory tests such as complete blood count, erythrocyte sedimentation rate, renal function tests and lipid profile were within normal limits, but with moderate hepatocytolysis syndrome (glutamate pyruvate transaminase of $47 \mathrm{U} / \mathrm{L}$ and aspartate aminotransferase of 36,9 U/L) and increased creatine phosphokinase $(175,8$ $\mathrm{U} / \mathrm{L})$.

Analizing the electrocardiographic aspect, the presence of sinus rhythm was found, with a heart rate of 60 / minute, intermediate electrical axis, qS V1-V2 with ST segment elevation maximum $1.5 \mathrm{~mm}$ (characteristic aspect of left ventricular aneurysm) (Figure 1). Cardiac ultrasound found the presence of dilated left ventricle (left ventricular enddiastolic diameter $65 \mathrm{~mm}$, left ventricular endsistolic diameter $50 \mathrm{~mm}$ ), with moderate systolic dysfunction (ejection fraction of left ventricle $40 \%$ ) by apex and apical akinesis, apex aneurysm, small-walled atheroma, calcified plaques and type I diastolic dysfunction (Figure 2).

The abdominal ultrasound showed hepatic steatosis and prostate with homogeneous structure and slightly enlarged size.

The chest radiography showed no pathological aspects (without diffuse or focal lesions, free costal-phrenic sinuses, heart and mediastinum of normal size) (Figure 3 ).

The patient declares the presence of vertigo on admission so a radiography of the spine was performed, which objected the presence of the cervical interaprophyseal arthrosis (more obvious at C3-C4), congenital vertebral block at the level of the C2-C3 arches, the spondylolisthesis $\mathrm{C} 5-\mathrm{C}$ and anterior marginal osteophytes (Figure 4).

For a patient with a history of myocardial infarction and heart failure, the investigations includes, besides, the assessment of the left ventricular performance and the balance of risk factors or the evaluation of the effort capacity by testing with a cycloergometer or rolling carpet. Cardio-pulmonary stress testing is the most accurate as it provides the best information regarding functional capabilities, beyond the ejection fraction of the left ventricle, while maintaining current medication, including beta-blockers.

The stress test was performed on the cycloergometer, with the progressive increase of the exercise power by $10 \mathrm{~W} /$ minute, starting from the basal level of 10W until reaching the maximum level (respiratory exchange rate RER $>1$ ) or reaching the maximum predicted value for at least one of the following parameters: VO2, exercise intensity (W), heart rate, maximum voluntary ventilation, or up to the limitation caused by dyspnea or significant muscular fatigue. Continuous monitoring of the electrocardiogram, respiratory gases, respiratory volumes as well as flow rates and 


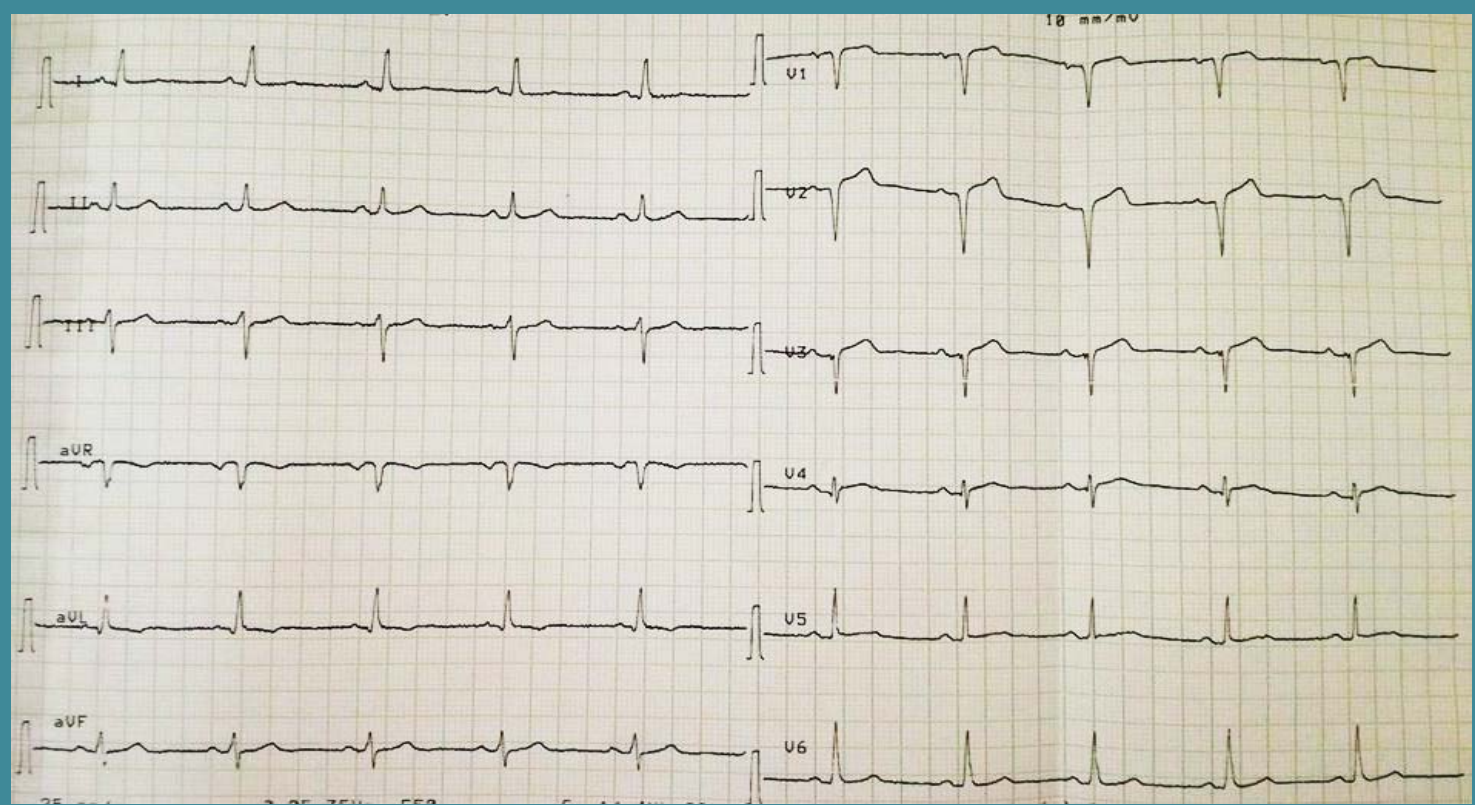

Figure 1. Electrocardiogram

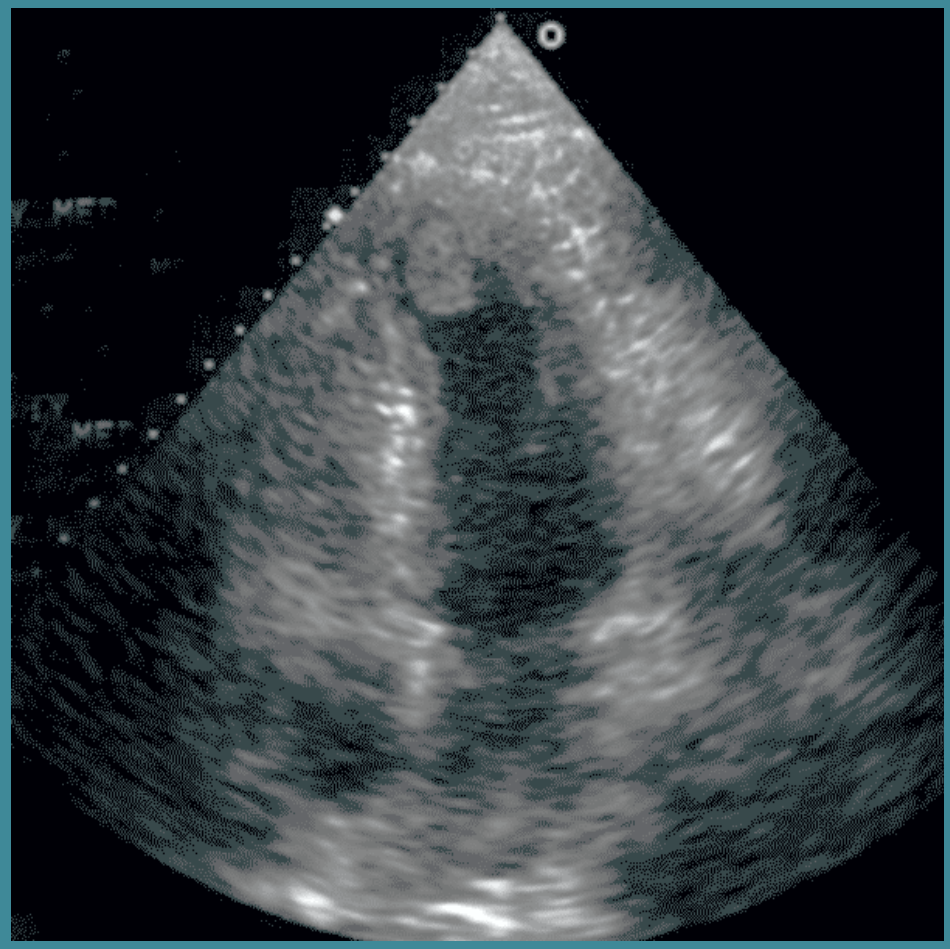

Figure 2. Ecocardiography 
INTERNAL

Clinical Cases.

serial monitoring of blood pressure at intervals of 2 minutes were performed. The stress test showed the following results:

- Maximum oxygen level: a maximum value of $117 \mathrm{~W}$ of stress level was reached $(59 \%$ of

- the maximum predicted value);

- Oxygen consumption: maximum value of $1303 \mathrm{ml} / \mathrm{minute}(54 \%$ of the maximum predicted value); this normalized value for body mass was of $13.5 \mathrm{ml} / \mathrm{kg} / \mathrm{min}$ suggestive for a moderate - severe functional alteration (Weber class C).

- Anaerobic threshold - was determined at a value of $1247 \mathrm{ml} /$ minute of oxygen consumption; the value of oxygen consumption at the anaerobic threshold, normalized for body mass, was $13.5 \mathrm{ml}$ / $\mathrm{kg} / \mathrm{min}$, suggestive of a mild-moderate functional alteration (Weber class B).

- Respiratory exchange rate (RER = VCO2/V02) recorded a value of 1.03 when reaching the maximum value of the physical exercise

- Heart rate response to exercise - the heart rate had a rest value of 79 beats / minute, reaching a maximum value of 120 beats / minute $(72 \%$ of the maximum predicted value); the pulse of oxygen was $11.9 \mathrm{ml} /$ beat ( $82 \%$ of the predicted value); the recovery of the heart rate at 1 minute from the moment of stopping the test was 8 beats / minute.

- Blood pressure response to effort - it had a baseline value of $100 / 70 \mathrm{mmHg}$, increasing to maximum values of 160/90 mmHg.

- Electrocardiogram: no significant changes compared to rest recording.

\section{Conclusions}

Cardiopulmonary testing shows a mild moderate alteration of functional effort capacity (Weber B class) and a target value of 100 beats / minute of heart rate during aerobic exercise is recommended. (Fig. 5-12). Our patient entered the clinic's records in 2017 when drug treatment with ARNI (angiotensin receptor-neprilysin inhibitor), was started at the recommended dosage guidelines (49/51 mg twice a day). At 6 months following the clinical and paraclinical improvement (especially of the ejection fraction), the first cardiopulmonary test was performed, followed one year later by a reassessment. As can be seen from the table below (Table 1), the parameters evaluated during the stress test were improved following the treatment with ARNI which is clinically transposed by improving the quality of life and implicitly the long-term prognosis.

Considering the symptomatology described by the patient on admission, the anklebrachial index was perfomed and the value 


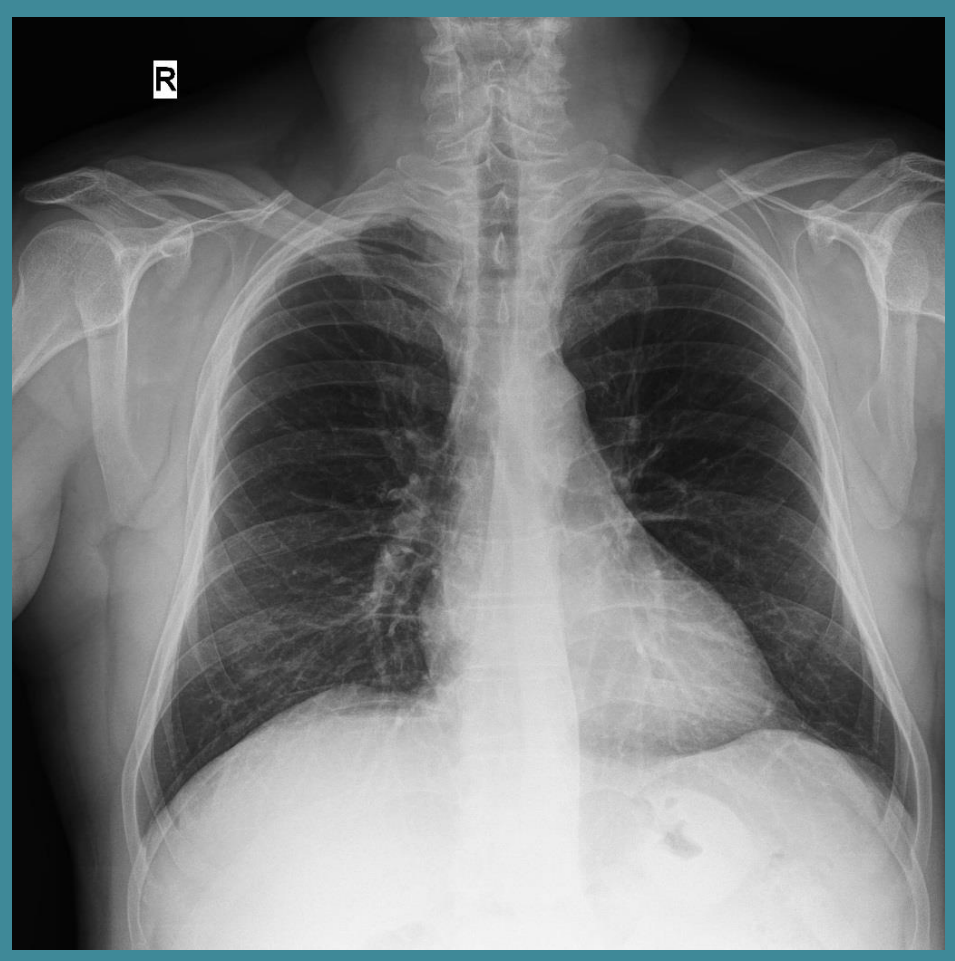

Figure 3. Chest X-Ray
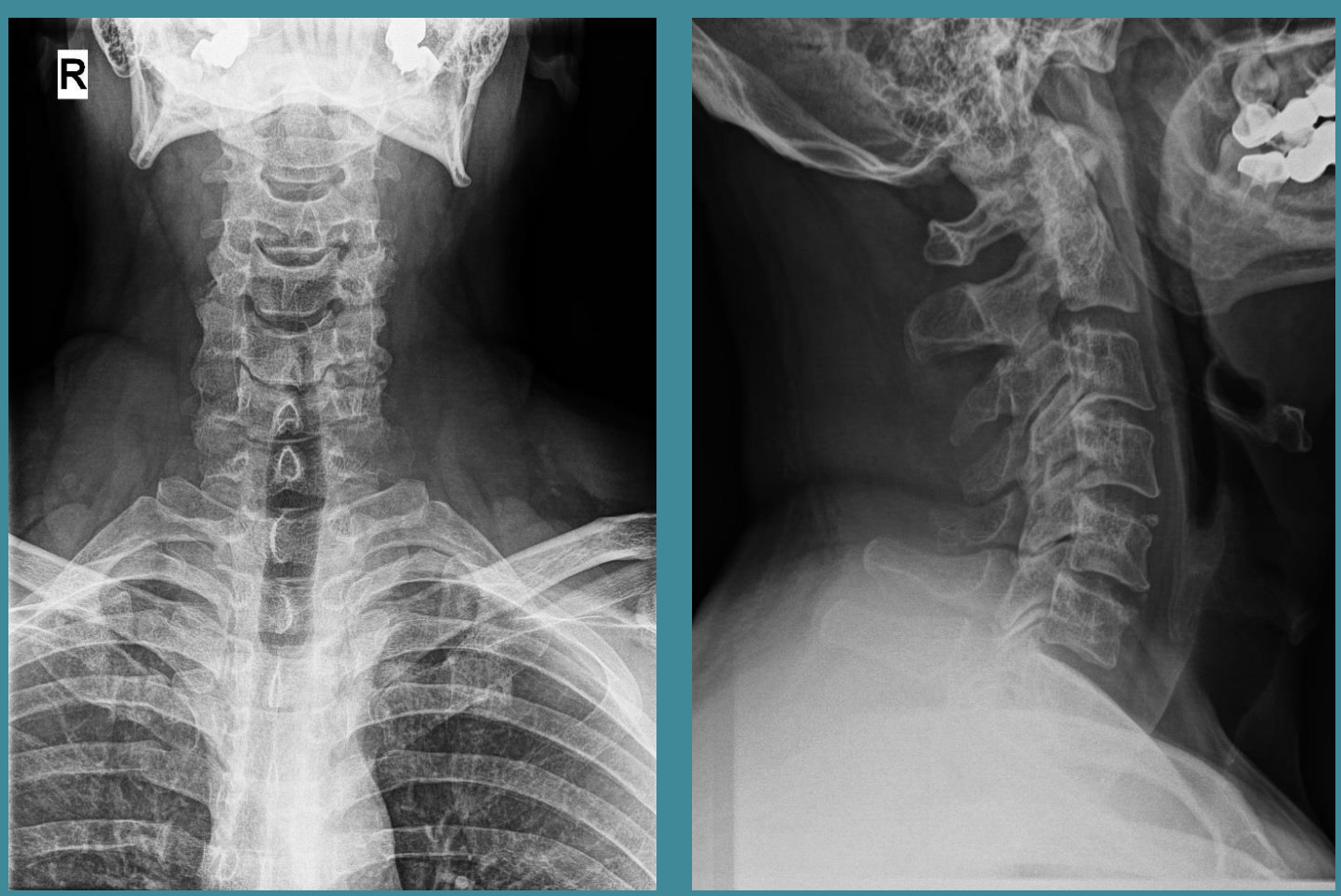

Figure 4. Cervical spine x-ray 


\section{INTERNAL}

\section{Clinical Cases}

was within normal limits, thus excluding the obliterating arteriopathy of the lower limbs.

\section{Differential diagnosis}

Considering the symptomatology of the patient described at the hospitalization, it was considered appropriate to make the differential diagnosis of dyspnea:

1. Cardiac dyspnea - is an inspiratory dyspnoea, accompanied by polynees

2. Dyspnoea of non-cardiac causes:

- Pulmonary diseases of the respiratory tract and pleura: pneumonia, pneumothorax, pleurisy, bronchial asthma, chronic obstructive bronchopneumopathy;

- Musculoskeletal chest pathology: skeletal abnormalities or neuromuscular diseases;

- Systemic disorders: thyroid toxicity, anemia, metabolic acidosis.

In the case of the muscular pains in the lower limbs, the differential diagnosis is made between the following entities:

- diabetic sensory-motor polyneuropathy;

- trauma;

- obliterating arteriopathy of the lower limbs;

- intolerance to statins.

\section{Positive diagnosis}

Corroborating the anamnestic, and clinicoparaclinical details obtained, the following positive diagnoses were established:

1. Chronic heart failure class II NYHA with moderate reduced ejection fraction

2. Old antero-lateral myocardial infarction (trombolysed)

3. Left ventricular aneurysm

4. Essential hypertension grade 3 very high risk

5. Type 2 diabetes complicated (with insulin treatment)

6. Chronic kidney disease stage II

7. Sensitive-motor peripheral diabetic polyneuropathy

8. Hepatic steatosis

9. Hypercholesterolemia (under treatment)

10. Statin intolerance

\section{Treatment}

During the hospitalization, the patient complied with the hygienic-dietary indications given at admission (low sodium and low lipid diet, avoiding the fats of animal origin, adequate hydration, respecting the physiokinotherapy recommendations reaching the targets indicated by the cardiopulmonary stress test) and followed treatment with Sacubitril / Valsartan 49/51 mg twice a day, Bisoprolol 5 mg daily, Clopidogrel 75 mg daily, and Rosuvastatin 10 mg daily.

When the patient was discharged, recommendations were made regarding lifesyle changes and medication: 


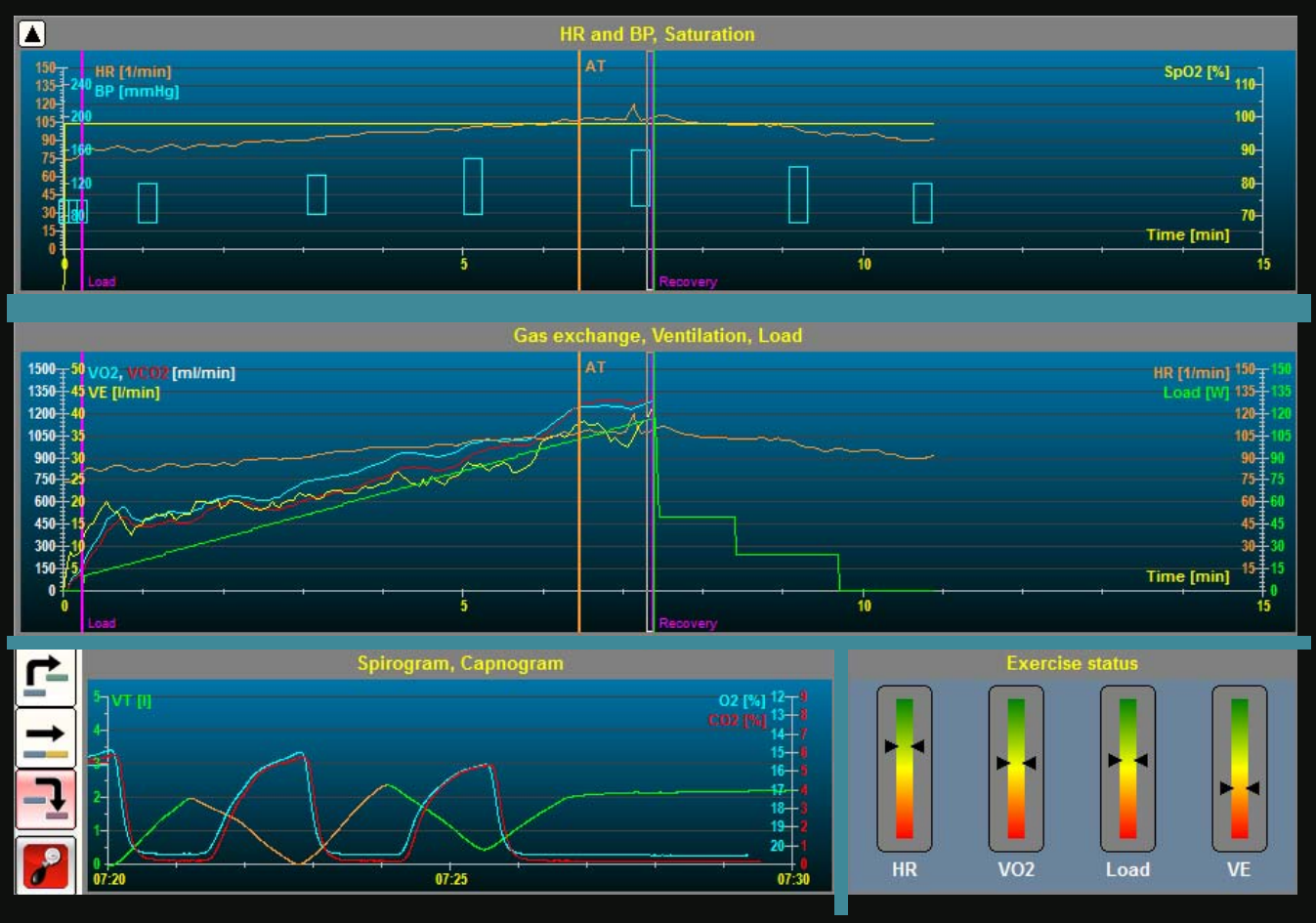

Figure 5. Parameters during the stress test (2019)

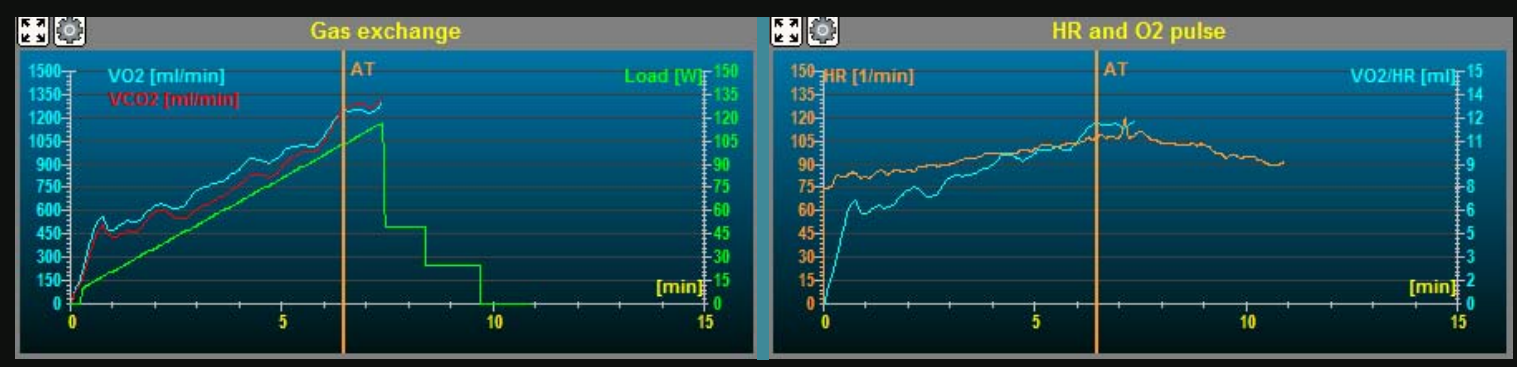

Figure 6. Parameters during the stress test (2019)

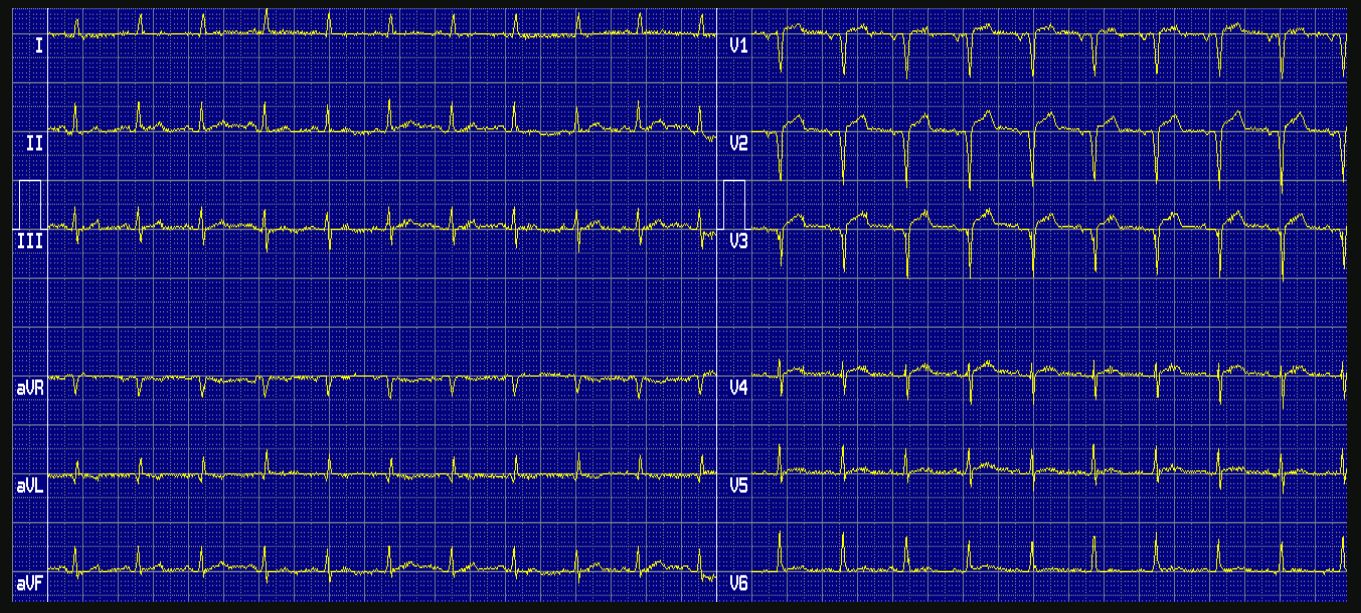

Figure 7. Electrocardiogram during the stress test (2019) 


\section{INTER}

Clinical Cases.

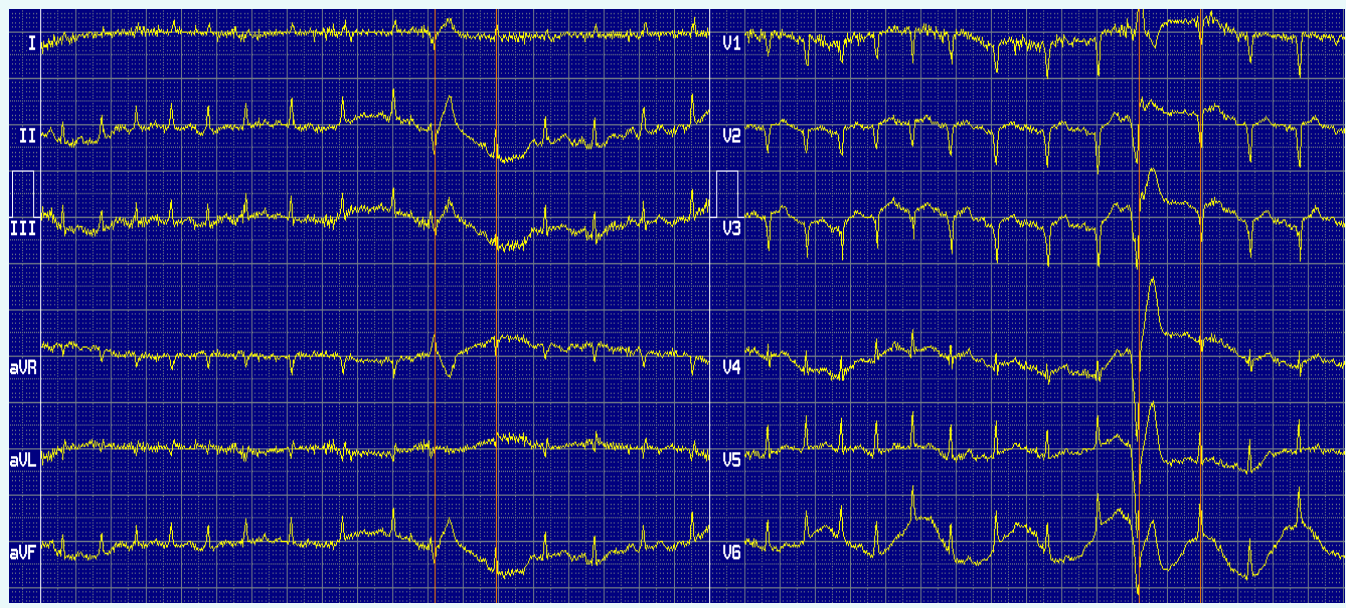

Figure 8. Electrocardiogram during the stress test (2019)

Diet and lifestyle:

- low sodium, low lipid diet, avoiding animal fats,

- aerobic physical effort within the tolerability limit, avoiding psychoemotional stress or extreme temperatures,

- adequate hydration (minimum 2 litres of water daily),

- continuation of physical training at home,

- periodic cardiological control,

- periodic monitoring of blood pressure and heart rate at home and in primary care,

Medication:

- Sacubitril / Valsartan 49/51 mg twice a day, Bisoprolol 5 mg daily, Clopidogrel 75 mg daily, and Rosuvastatin 10 mg daily.

\section{Evolution}

During hospitalization, the initial symptoms improved under the use of medication and blood pressure profile, the biological parameters and the hemodynamic ones remained within normal limits. The patient attended physiotherapy sessions with the targets suggested by the cardiopulmonary stress test, with both immediate and longterm benefits, thus ensuring a quality of life corresponding to a patient of only 53 years old.

\section{Prognosis}

- short-term: relatively good, considering the presence of heart failure with moderated diminished ejection fraction (discreetly improved compared to the last evaluation);

- in the long term: prognosis marked by the natural evolution of heart failure 


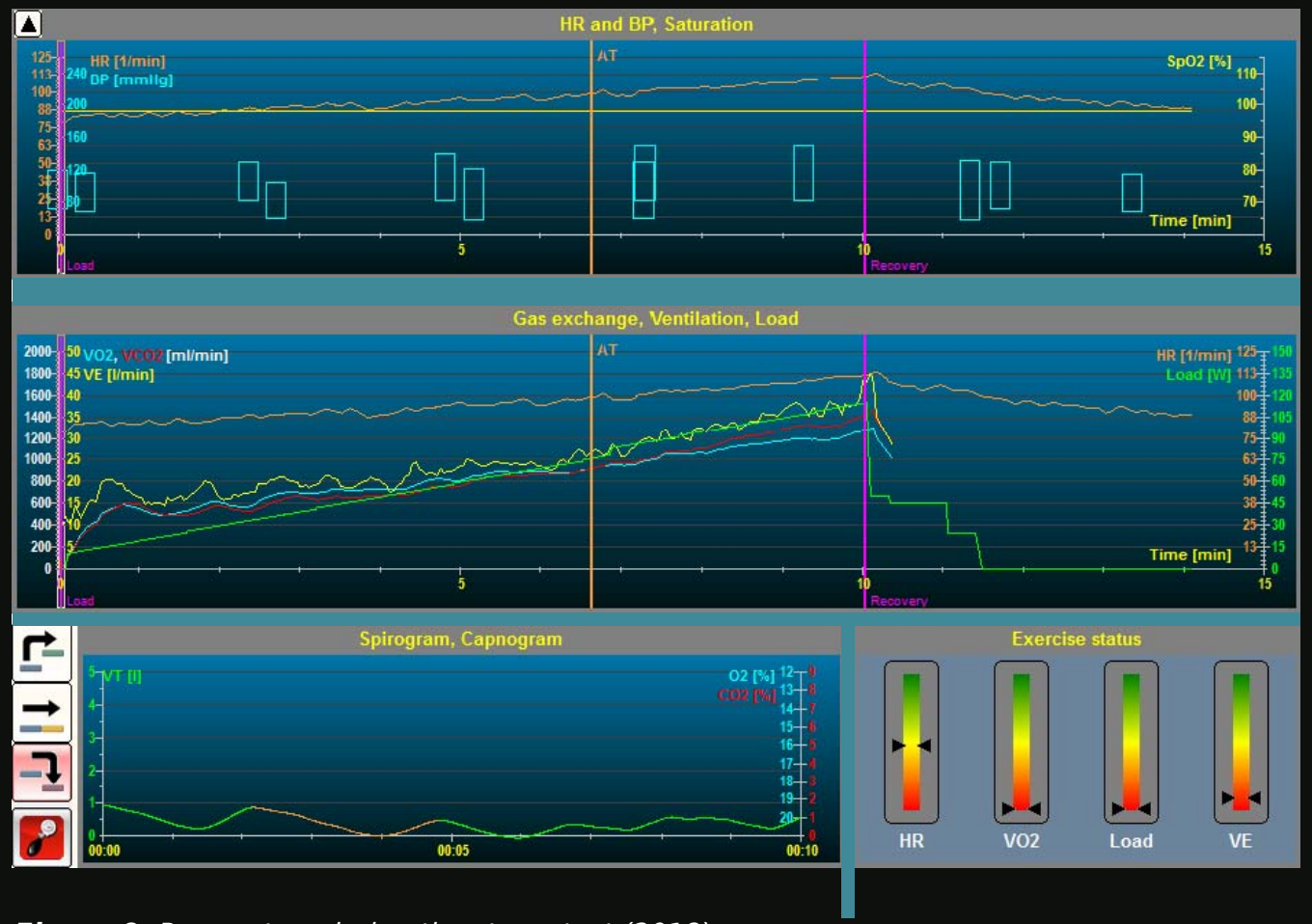

Figure 9. Parameters during the stress test (2018)

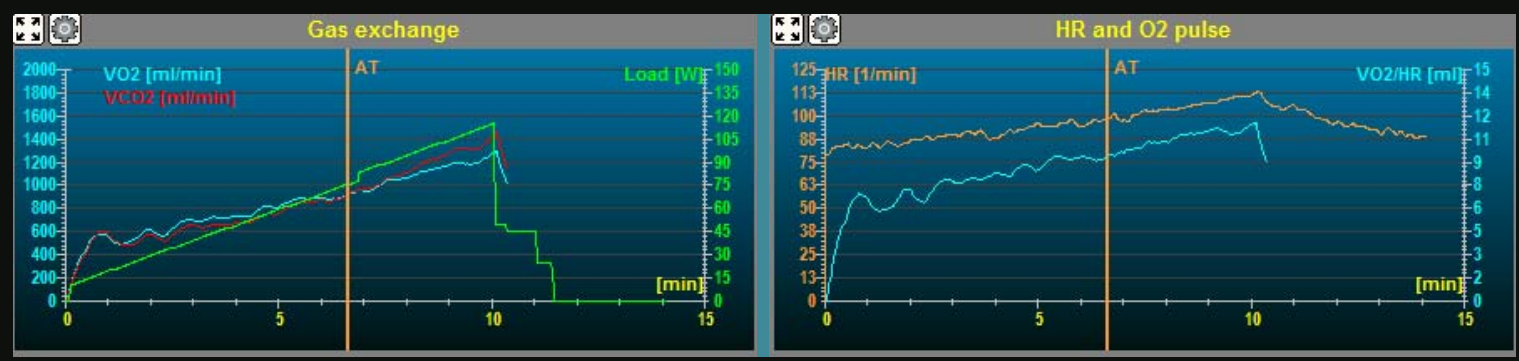

Figure 10. Blood pressure and oxygen volume during the stress test 2018

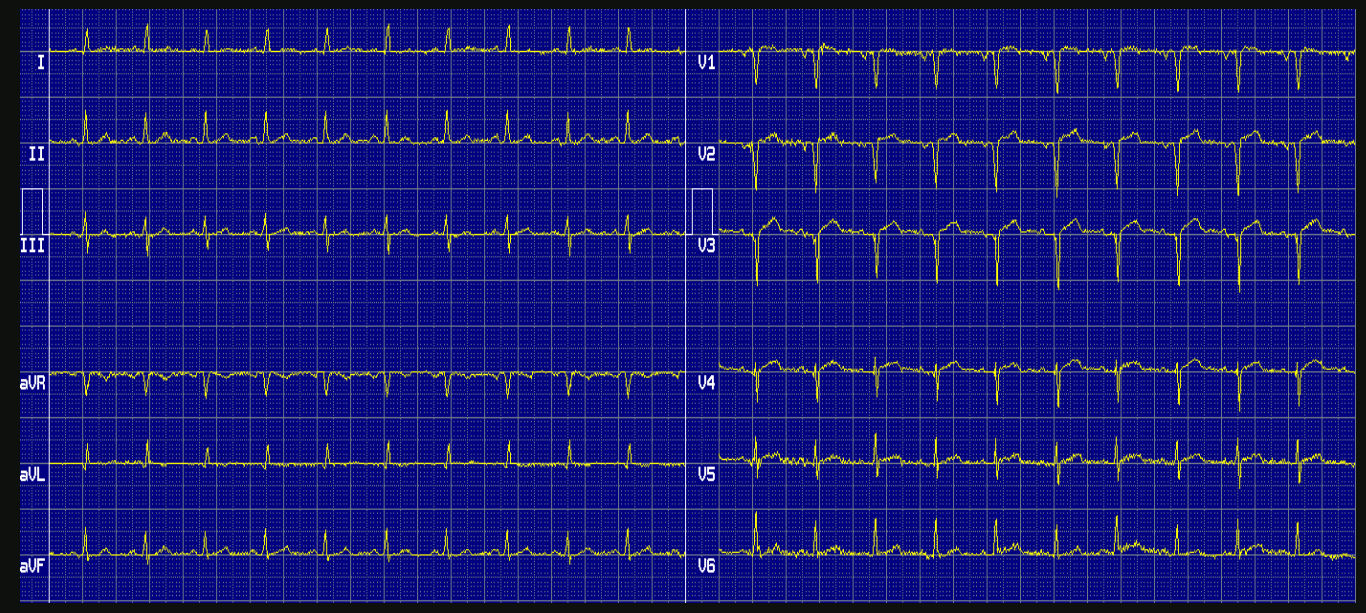

Figure 11. Electrocardiogram during the stress test (2018) 


\section{Cinical cases.}

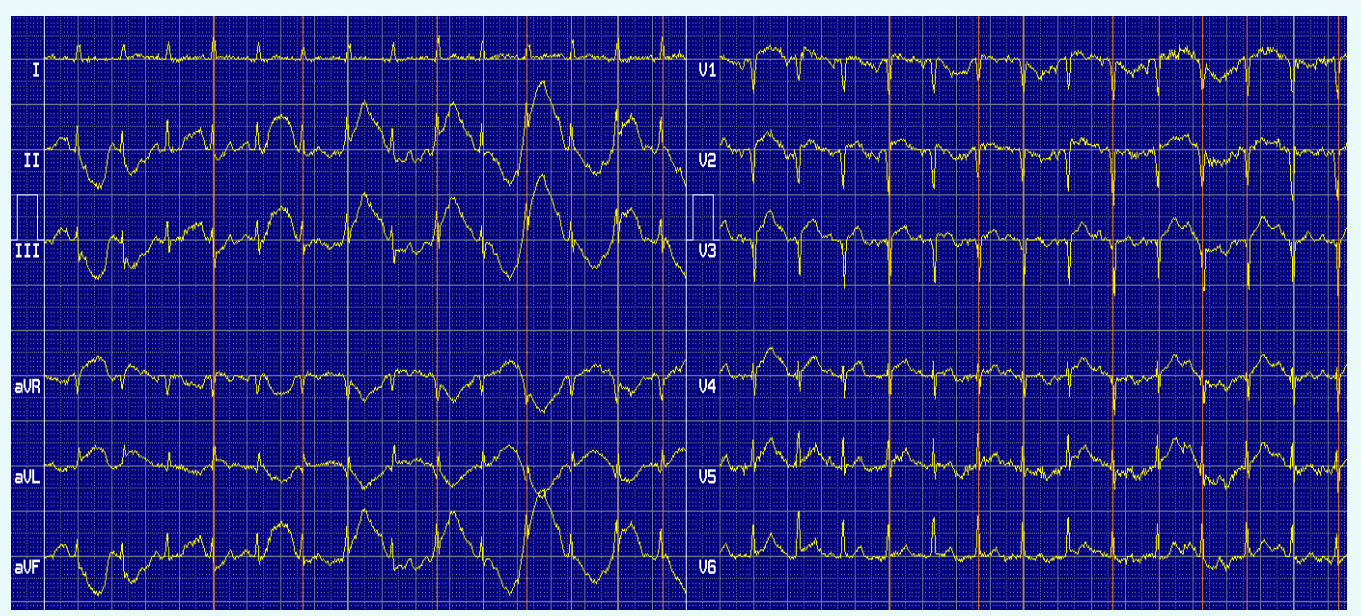

Figure 12. Electrocardiogram during the stress test (2018)

and the negative impact of possible decompensations, the association of diabetes mellitus and the limitation of this intolerance that prevents the administration of statin at the recommended doses of guides.

\section{Discussions}

The etiology of acute myocardial infarction differs from case to case, mainly being represented by the occlusion of a large coronary artery produced secondary to intracoronary thrombosis. In about $10 \%$ of cases, the infarction occurs in the absence of coronary atherosclerosis, the main causes being arteritis, traumatic coronary arteries, congenital anomalies of the coronary arteries, embolisms at this level, hematological causes (true policitemia, thrombocytosis, disseminated intravascular coagulation, thrombocytopenic purpura) or cocaine use ${ }^{(1,2)}$. Increased beta-adrenergic stimulation, hypercoagulability and platelet hyperreactivity together with excessive physical and emotional stress can be considered triggering factors for atheroma plaque rupture and coronary thrombosis. Specialized literature points out in many studies the main causes of acute myocardial infarction among young patients. Whether it is congenital abnormalities such as spontaneous dissection or coronary artery aneurysm (commonly diagnosed at autopsy), secondary embolization of infectious endocarditis on the aortic valve, presence of antifofolipid syndrome, whether or not associated with other autoimmune pathology, or a mutation, determines the status procoagulant with a high associated risk 


\begin{tabular}{|c|c|c|}
\hline \multicolumn{3}{|c|}{ Cardio-pulmonary stress testing } \\
\hline Parameter & 2018 & 2019 \\
\hline Maximum effort level & $\begin{array}{l}115 \mathrm{~W} \\
\text { ( } 57 \% \text { of the maximum } \\
\text { predicted value) }\end{array}$ & $\begin{array}{l}117 \mathrm{~W} \\
\text { ( } 59 \% \text { of the maximum } \\
\text { predicted value) }\end{array}$ \\
\hline Oxygen consumption & $\begin{array}{l}1293 \mathrm{ml} / \mathrm{min} \\
\text { ( } 53 \% \text { of the maximum } \\
\text { predicted value) }\end{array}$ & $\begin{array}{l}1303 \mathrm{ml} / \mathrm{min} \\
\text { ( } 54 \% \text { of the maximum } \\
\text { predicted value) }\end{array}$ \\
\hline Anaerobic threshold & $919 \mathrm{ml} / \mathrm{min}$ & $1247 \mathrm{ml} / \mathrm{min}$ \\
\hline Respiratory exchange rate & 1,11 & 1,03 \\
\hline Ventilatory response & 45 litri/minut & 48 litri/minut \\
\hline $\begin{array}{l}\text { Heart rate response to } \\
\text { exercise }\end{array}$ & $\begin{array}{l}\text { Maximum: } 113 \mathrm{bpm} \\
\text { ( } 67 \% \text { of the maximum } \\
\text { predicted value) }\end{array}$ & $\begin{array}{l}\text { Maximum: } 120 \mathrm{bpm} \\
\text { ( } 82 \% \text { of the maximum } \\
\text { predicted value) }\end{array}$ \\
\hline $\begin{array}{l}\text { Blood pressure response to } \\
\text { exercise }\end{array}$ & Maximum: 150/80 mmHg & Maximum: 160/90 mmHg \\
\hline Electrocardiogram & $\begin{array}{l}\text { No significant changes } \\
\text { compared to rest recording }\end{array}$ & $\begin{array}{l}\text { No significant changes } \\
\text { compared to rest recording }\end{array}$ \\
\hline
\end{tabular}

Table 1. Cardio-pulmonary stress testing (2018 and 2019) 


\section{INTERNAL}

\section{Clinical Cases}

especially in smokers, all these causes outline the picture of a pathology with a different presentation mode than that of the elderly ${ }^{(2,3)}$. The typical picture represented by angina pectorendo crescendo that evolutionarily associated with a great angina crisis does not appear among young patients, typical for them being angina pain with onset and rapid evolution.

Anamnesis plays an essential role in stratifying the risk and choosing the optimal therapeutic management for each case, in order to obtain the maximum benefit, both short and long term ${ }^{(3,4)}$. Thus details such as intravenous drug use, heredocolateral history of sudden death or cardiovascular disease at a young age, the combination of the classic cardiovascular risk factors or the history of arterial or venous thrombosis guides and facilitates the diagnosis at an early stage ${ }^{(1,2,5)}$.

\section{Conclusion}

The causes for myocardial infarction among patients aged less than 45 can be divided into four groups: atheromatous coronary heart disease, non-atheromatous coronary heart disease, hypercoagulable states and myocardial infarction related to substance misuse. The particularity of this case consists in the occurrence of myocardial infarction at a young age (36 years) in a patient without a heredocolateral history or associated risk factors at that time and who after the acute event develops a severe chronic heart failure with important life-threatening limitations and prognosis. long term. The association of ARNI (Sacubitril / Valsartan) in the therapeutic scheme has determined both a clinical improvement by the improvement of symptoms, as well as paraclinical especially regarding the echocardiographic parameters (the ejection fraction increased from $25 \%$ to $40 \%$ at the end of the evaluation).

\section{Bibliography}

1. Rajeev Bhardwaj, Arvind Kandoria, Rajesh Sharma. Myocardial infarction in young adults-risk factors and pattern of coronary artery involvement. Niger Med J. 2014 Jan-Feb; 55(1): 44-47

2. Osula S, Bell GM, Hornung RS. Acute myocardial infarction in young adults: causes and management. Postgraduate Medical Journal 2002;78:27-30.

3. Ge J, Li J, Yu H, An Y. Acute myocardial infarction in young adults: Risk factors, clinical features, and management strategies. Cardiol Plus 2017;2:21-5

4. Choudhury, Lubna et al. Myocardial infarction in young patients. The American Journal of Medicine, Volume 107, Issue 3, 254 - 261

5. Srikanth Yandrapalli, Christopher Nabors, Abhishek Goyal, Wilbert S. Aronow and William H. Frishman. Modifiable Risk Factors in Young Adults With First Myocardial Infarction. Journal of the American College of Cardiology. Volume 73, Issue 5, February 2019 